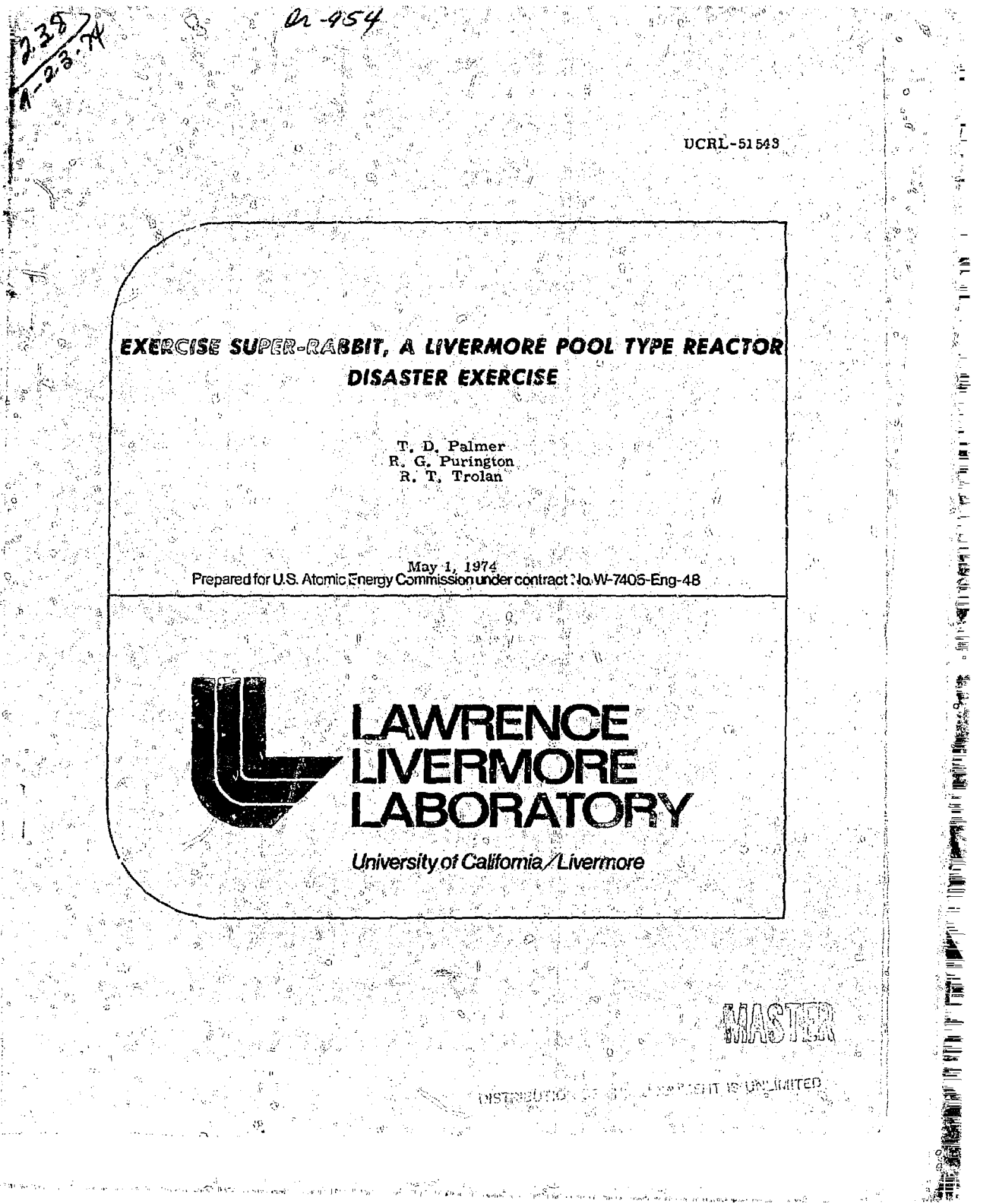


TID-4500, UC 41

Health and Safety

\section{近 \\ LAWRENCE LJERIMORE LABORATORY \\ University of Caftornia. Lvermora, Calromia/s4550}

UCRL- 51543

\section{EXERCISE SUPER-RABBIT, A LIVERMORE POOL TYPE REACTOR DISASTER EXERCISE}

T. D. Paimer

R. G. Purington

R. T. Trolan

MS, date: May 1, 1974

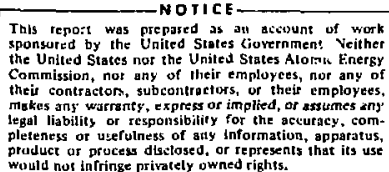

, or represents that its use

would not in fringe privately owned rights. 


\section{Contents}

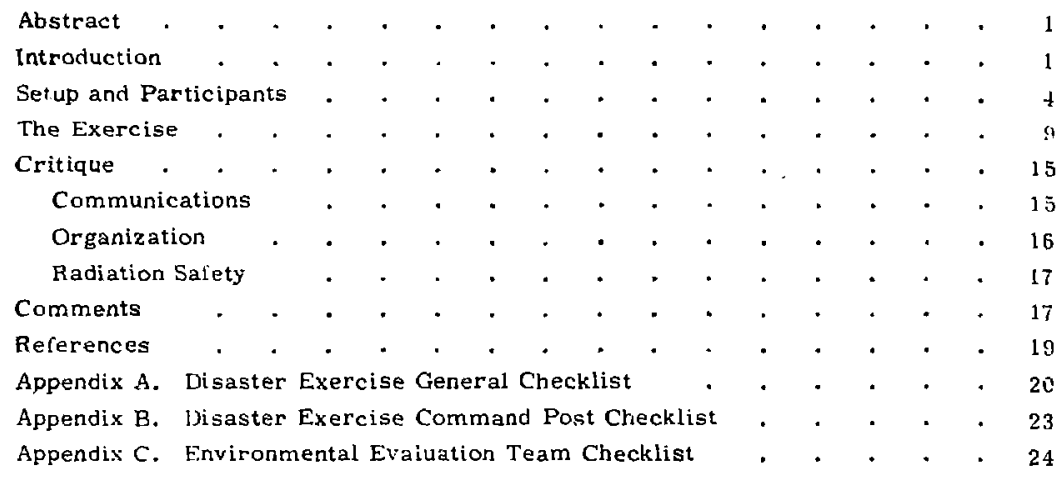




\title{
EXERCISE SUPER-RABBIT, A LIVERMORE POOL TYPE REACTOR DISASTER EXERCISE
}

\begin{abstract}
A simulated disaster designed to exercise the LLL Disaster Control Plan, the Livermore Pool Type Reactor (LPTR) Disaster Control Plan, and the various LLL disaster control support organizations and facilities is described. $A$ simulated LPTR experiment, which resulted in damage to the reactor and injuries to reactor personnel, renuired response to an uncontrollable reactor, rescue and evacuation of contaminated victims in a high radiation field, decontamination of facilities and personnel,

and medical attention for injured operations personnel. The exercise required an alert of the LLL emergency response system and subsequent upgrading from a local accident status to that of a major disaster. The LLL Disaster Control Organization and required support units responded and implemented the LLL and LPTR Disaster Control Plans. Evaluation of the response was provided by umpires and followed by a critique of all personnel involved in the exercise.
\end{abstract}

\section{Introduction}

Practice exercises are regularly held at LLL to evaluate the Laboratory's disaster plans and to ready personnel for possible disasters. Exercise SuperRabbit, held in December, 1973, was the most comprehensive exercise ever condricted. Both the seriousness of the mock disaster and the resulting large numbers of people required to respond were unique.

Exercise Super-Rabbit was the result of over a month of planting by the Hazards Control Department. It was staged at the Livermore Pool Type Reactor (LPTR) Building, in the street outside the building, and at various LLL support facilities, such as the Medical Department.
A simulated explosion in the LPTR started the 80-minute-long exercise. The results of the explosion were that the reactor was out of control and widespread radiation contamination was possible if it was not brought under control.

The LLL Disaster Control Organization and its support units (Figs. 1 and 2) were required to respond to the accident and to implement the LLL and the LPTR Disaster Control Plans. The major objectives of the exercise were to test the LPTR plan, ${ }^{1}$ which had never before been tested, the LLI Disaster Control Plan, ${ }^{2}$ and supportive plans. ${ }^{3,4}$

Additional objectives of the exercise were: 


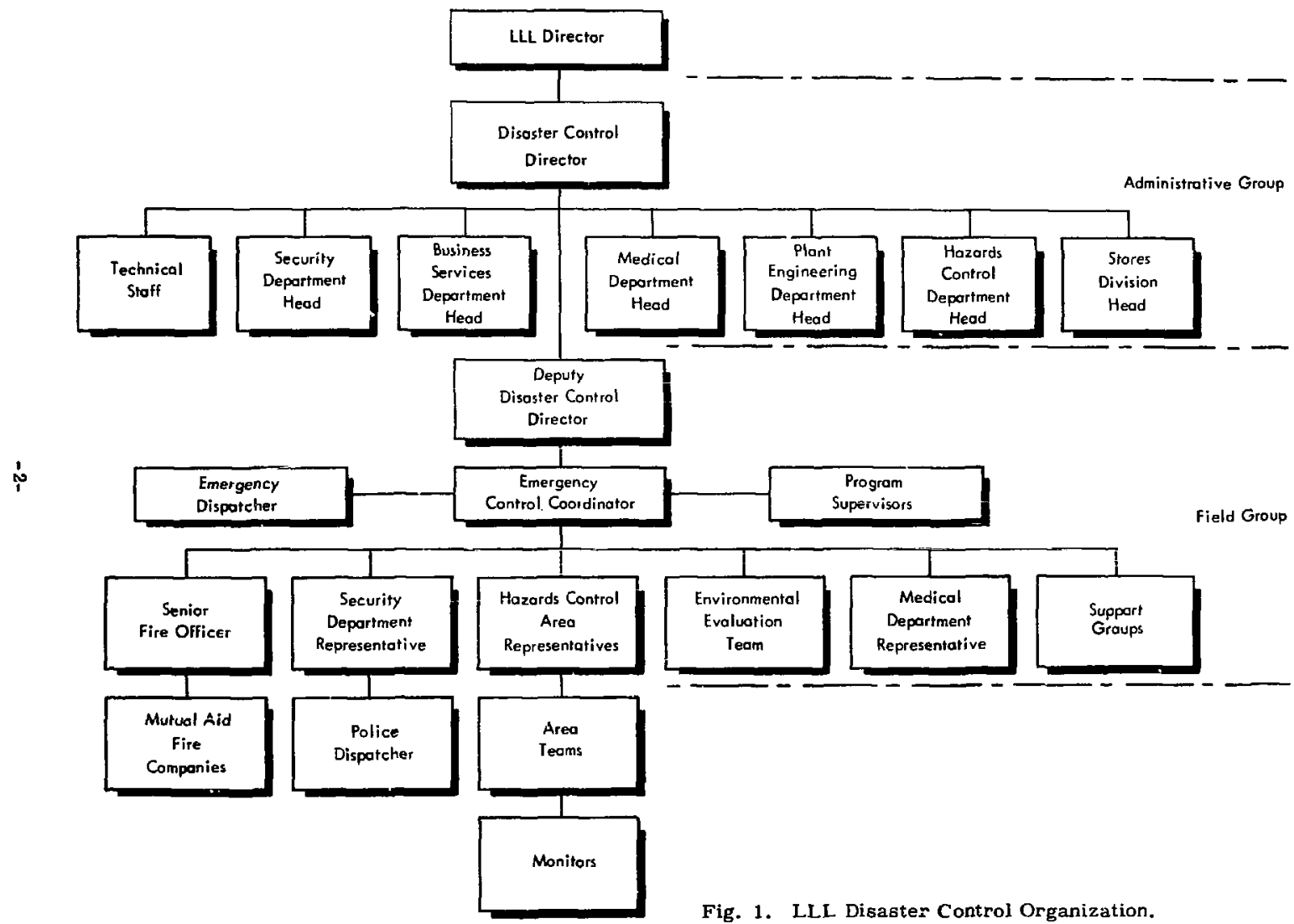

Fig. 1. LLL Disaster Control Organization. 

treatment of contaminated and injured victims.

- To test the response of the LPTR operations staff to a reactor disaster problem and to test the effectiveness of their emergency training in determining what caused the reactor to misfunction and in bringing it under control.

Exercise controls and limitations were adopted as a safety precaution. The use of equipment and the actions of all participants were limited to what could be safely done, Actions which could conceivably result in real accidents or serious equipment damage were to be terminated immediately. Each person participating in the succession of notifications, instructions, alerts, telephone calls, or radio transmissions used in the exercise first advised the contact that "This is an exercise" and thereafter requested response to exercise activities.

Other precautions included the assignment of safety responsibilities to specific people. The Disaster Director or his deputies were to request all personnel to cancel or delay the exercise in the event of an actual emergency. The Hazards Control Department Exercise Coordinator and designated exercise umpires were responsible for guiding the execution and direction of the exercise. The Reactor Supervisor stayed in the reactor control room of the I.PTR building and supervised reactor operations throughout the exercise. He verified that the reactor was maintained in a safe configuration at all times and retained the authority to discontinue the exercise any time he felt the safety of the reactor was being compromised.

\section{Setup and Participants}

The exercise is baged on an accident that involves the explosion of nuclear material in the LPTR during an experiment. (Figure 3 shows the LPTR Building, Fig. 4 shows its floor plan, and Fig. 5 shows the LPTR control room console,) An accident was planned that might logically occur during the use of the LPTR equipment. Existing LPTR procedures for the use of the reactor in experiments were followed, startin[" with the requisitioning of machine time by two experimenters. The explosion occurs in the LPTR fast-rabbit irradiation equipment. This is a pressure-operated tube system designed to move a small projectile (the rabbit) fr $\mathrm{cm}$ - lacoratory staging area into the LPTR fCr irrediation of samples placed inside the rabbit. Normally, after a programmed length of time, the projectile is automatically returned through the tube system to the staging area. In this exercise, the rabbit fails to return and two people enter the reactor dome (where the equipment $[\theta]$ to check out the rabbit tube syotem. During their checkout of the malfunction, the rabbit explodes. The cause given for the simulated explos; on is that an oversized fissible sample has generated enough excess heat to vaporize the liquid sample. The two people in the reactor dome are wounded and radioar rely contaminated by the explosion. The , zeults of the explosion are the reactor is out of control, radioactive water vapor and radioactive 

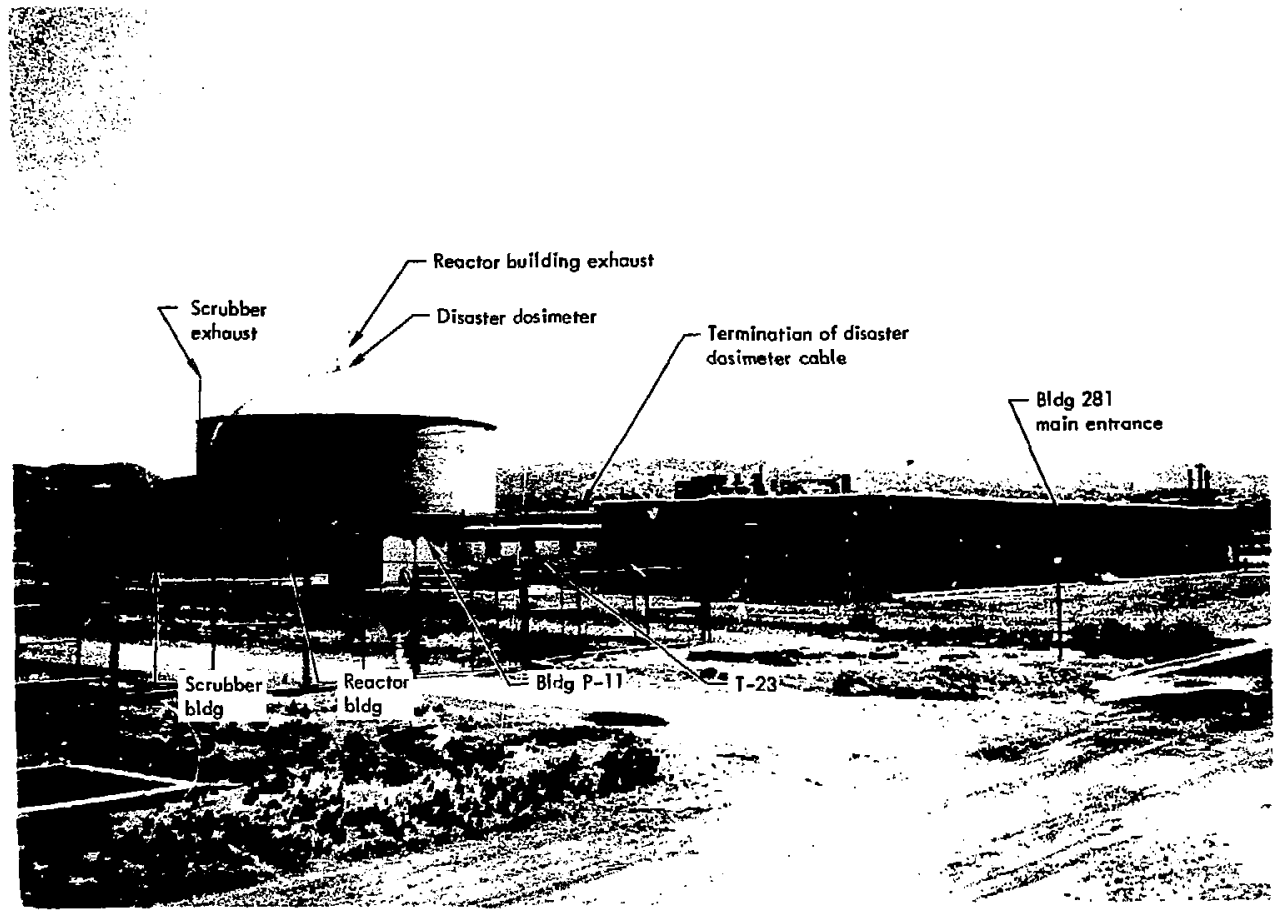

Fig. 3, General view of the Livermore Pool rype Reactor Building. 


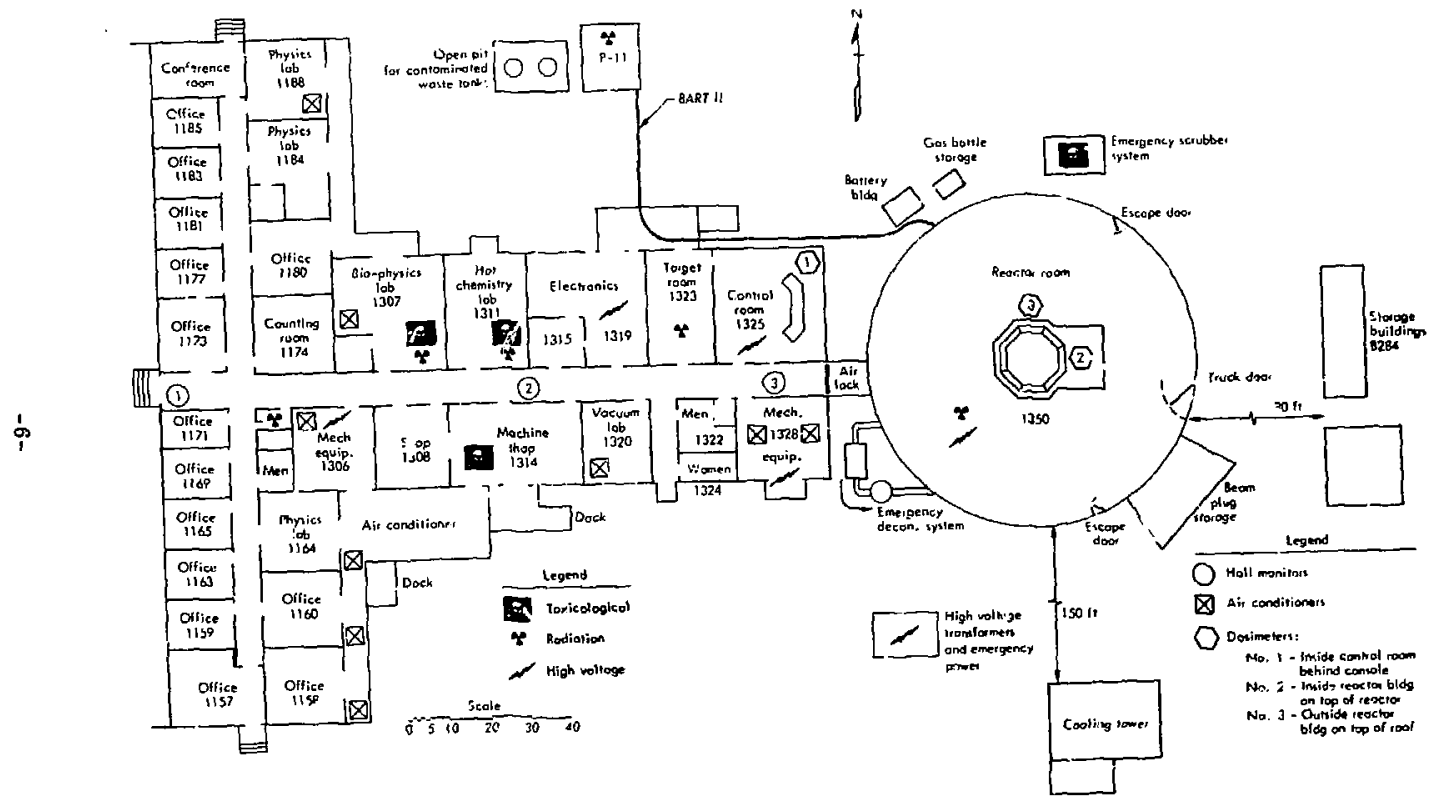

I'g. 4. Floor plan ef th. LPT R Builing 281 and associated structures. 


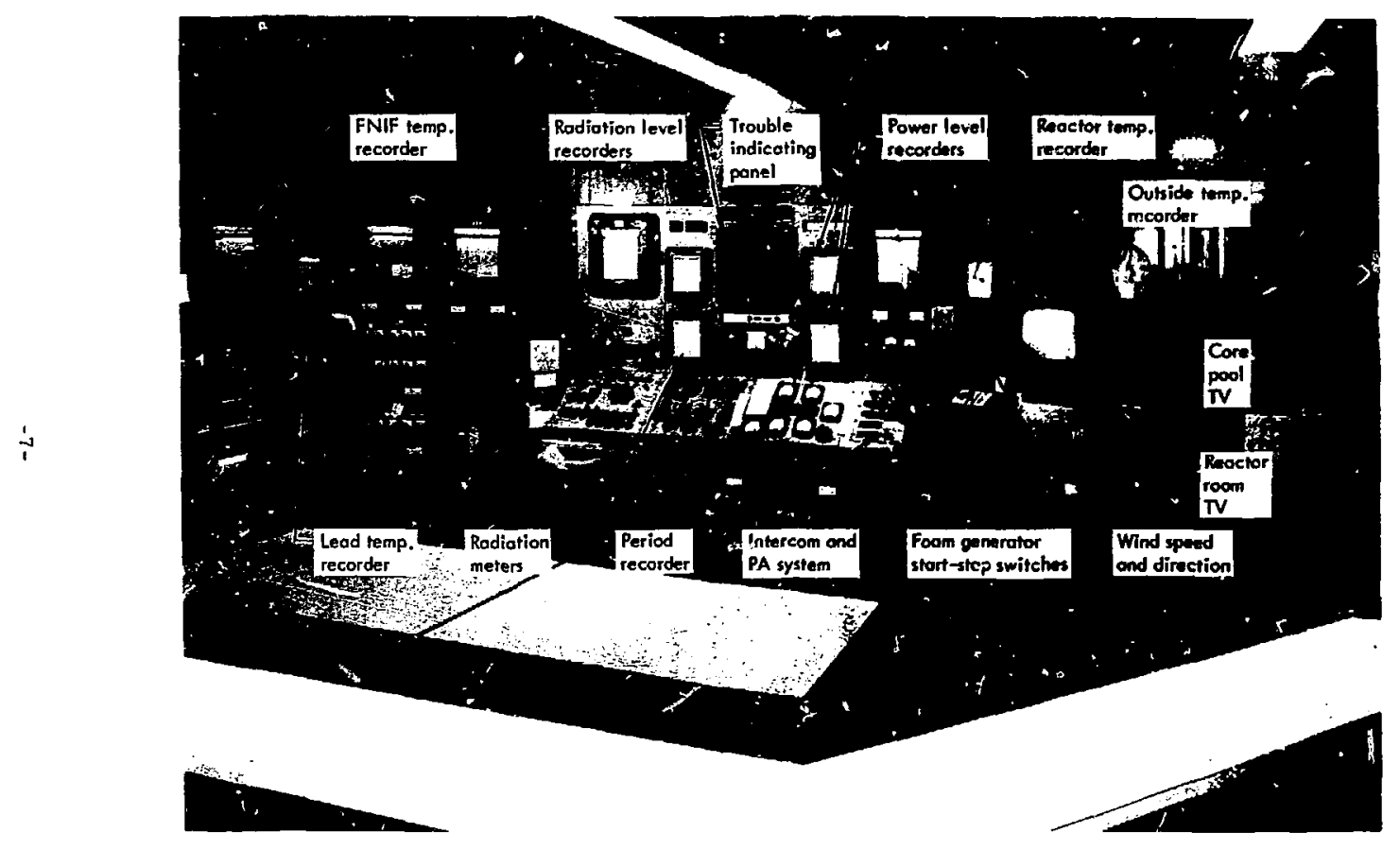

Fig. 5. LPTh control console in the reactor control room, 1325 . 
particles are spewed into the reactor domes atmosphere, spread of radicactive contaminat:on is po3sible, and there is a chance of ofi-site radiation release if the reactor is not brought under control.

Exercise Super-Rabbit was carefully desisned to closely imitate a disaster. For this reason, most of the personnel requires "o respond were not aware of the date or rature of the test before it occuired. The two men injured by the explosio: were made up to look wounded. Coleman ${ }^{*}$ lantern mantles were attached to their clothes and injuries to simulate radiation contamination. The mantles contain ThO in sufficient quantities to serve as a low-level radiation source. Recalibrated radiation meters picked this up as a high reading. Other instruments were recalibrated and manipulal ad to give readings expected in this type of disaster. A radiation field was simulated within the reactor dome area (where the explosion occurs) by use of low-level radiation sources and the recalibrated detection inrtruments. Levels simulated varied from 500 to $1000 \mathrm{R} / \mathrm{hr}$, extremely large amounts of radiation. Other steps taken to simulate a real explosion included scattering debris representing exploded tubing and a damaged rabbit around the reactor floor anc landing. The reactor operating status light was adjusted to read "Reactor-On" to simulate failure to shut down. In addition, the reactor dome intercom system and the television display of the dome monitoring camera

\footnotetext{
Reference to a company or product nari. " wes not imply approval or recommenciution of the product by the University of California or the U.S. Atomic Energy Commission to the exclusion of others that may be suitable.
}

were turned off to aimulate damaged syetems. Sound effects of bolling water and the rattling of rods simulating reactor cors and rod damage were played over the reactor speaker to the control room. The power level recording strip chart was changed from the normal 3.0-MW level to read $3.5 \mathrm{MW}$, representing an uncontrolled power increase. The reactor pool liquid level gage was labeled to insicate a gradual loss of water. The reactor low coolant flow indicator light was on. The conditions simulated indicatid a reactor in uncontrollable condition. The power was ircreasing and the water level decreasing. The :eactor could not be shut down and the reason for the water loss was uni:nown.

Following an initial sizeup of the problem, the nature of the accident rem quired upgrading it from accilent to disaster status and required mobilization of the LIL Disaster Control Organization (Figs. 1 and 2), the Hazards Control Department Emergency Response staff and field team, the LPTR Operations staf:. the Emergency Assistance Team. the Environmental Evaluation Team, and elements of the Hot Spot Team, Additiona: support was provided by the Police Department, the Medical Department, Iirectors' Office, and the Public Information staff.

An informal script was written to direct the exercise, and eight people were assigned parts. They were Experim unters 1 and 2, Hazard Control Technicians 1 and 2, newswian, Emergency Control Coordinator, fiazards Control Reacior Area Representative, and Reactor Supervisor. The script listed the eight people's specific duties and ad lib possibilities. 
Three of the players, the Emergency Control Courdinator, the Hazards Control Reactor Area Representative, and the Reactor Supervisor, are part of the IPTR Disaster Control field group (Fig. 2). In times of actual disaster, they have asaigned duties. In this exercise, they performe those duties and were assigned certain ' chers to help control the exercise.

Five members of the Hazards Control Department participated as playera with assigned roles and five others were umpires. The umpires were assigned observation stations. They were aware of the overall exercise plan and their job was to guide the flow of the exercise to completion and to prevent potentially hazardous actions by participants. They carefully observed the activity, recorded it, and later held critique sessions with the people in their areas. Checklists were used by the umpirio as guides to evaluate the emergency response. Appendixes A, $B$, and $C$ give sample checkliats. Umpire assigneinents were as follows. One person each was assigned to observe the effectiveness of: the generai exercise, the response to the LPTR Disaster Control Plan, the dispatclier's reaponse, the LPTR Building cvacuation, the Environmental Evaluation Team's response, crowd and traffic control, the Medical Department's response, the Emergency Control Coordinator who ran the exercise, and contamination control and radiation procedures. Pairs of umpires critiqued each of the following: the action inside the reactor dom $=$, the action outside the reactor dome, and the overall effectiveness of the response to the exercise.

The umpires' observations and the subsequent critigues were the basis for suggestions resulting from the exercise.

\section{The Exercise}

What follows is a detailing of the exercise as it occurred. Table 1 shows the timetable sequence. The entire exercise took place within 80 minutes, numerous people were involved, and many everits were occurring simultaneously or in very quick succession. In all ispects of the exercise, attempts were made to simulate a real disaster.

Immediately prior to the official start of the exercise, Experimenters 1 and 2 are conducting a simulated research experiment in reactor building 281 (Fig. 3), using the fast-rabbit equipment discussed above. Hazards Control Technician 1 and Experimenter 1 are in the reactor radio-chemistry laboratory and sample room (1311 and 1323) doing a sample rabbit shot with water as the simulated liquid fissible sample. See Fig. 4.

In the reactor control room, the Reactor Supervisor is also simulating a rea? rabbit shot, operating the controls to deliver and return the rabbit. In actuality, the rabbit is returned and the reactor is shut down. This signals the official start of the exercise and the Feactor Supervisor announces the start to the control room personnel. This is time zero on the timetable (Table 1 ). The Reactor Supervisor initiates the 
Table 1. Timetable

\begin{tabular}{|c|c|}
\hline 0 & $\begin{array}{l}\text { Reactor shutdown, announcement and start of exercise, klaxm } \\
\text { horn sounded, building evacuated. }\end{array}$ \\
\hline 2 & Fire command car, fire equipment, and disaster teams arrive. \\
\hline 4 & Wind conotion assessed, initial accident evaluation in progress. \\
\hline 6 & $\begin{array}{l}\text { Hot Lines established, Command Post manned, and disaster teams } \\
\text { teams arrive at scene. }\end{array}$ \\
\hline 8 & $\begin{array}{l}\text { Building entry and situation analysis in progress. Hazards } \\
\text { Control Technician } 2 \text { located and given first aid. }\end{array}$ \\
\hline 10 & $\begin{array}{l}\text { Situation upgraded from accident to disaster status and isaster } \\
\text { organization activated. Experimenter } 2 \text { located and sitdation } \\
\text { assessed. }\end{array}$ \\
\hline 12 & $\begin{array}{l}\text { Downwind and off-site surveillance started and monitoring system } \\
\text { put in to operation. }\end{array}$ \\
\hline 14 & $\begin{array}{l}\text { Hot Lines manned and radiation fields assess o. Experimenter } 2 \\
\text { prepared for removal. }\end{array}$ \\
\hline 16 & $\begin{array}{l}\text { Disaster organization and support equipment respondirg, } \\
\text { ambulances alerted, Criticality S: fety Committee arrives. }\end{array}$ \\
\hline 18 & Newsman arrives at West Gate. \\
\hline 20 & Ambulances arrive at scene. \\
\hline 24 & $\begin{array}{l}\text { Experimenter } 2 \text { noved through Hot Lines to ambulance and } \\
\text { transported to medical facility. }\end{array}$ \\
\hline 30 & $\begin{array}{l}\text { Hazards Control Technician } 2 \text { moved through Hot Lines to } \\
\text { ambulance. }\end{array}$ \\
\hline 40 & Hazards Control Technician 2 transported to medical facilities. \\
\hline 50 & Reactor damage assessment in progress. \\
\hline 60 & Reactor damage assessment completed. \\
\hline 70 & Reactor control plan developed. \\
\hline 80 & Exercise terminated. \\
\hline
\end{tabular}

exercise activities by informing the building's occupants that a drill is in progress. He makes and repeats the following announcement over the public address system: "Attention all building occupants, this is a drill. Please follow all instructions. An exercise of the LPTR Disaster Plan is in progress. Please respond to all alarm system requests. This is an exercise only. Please respond to all requests."
The acting part of the exercise begins at this point. The Reactor Supervisc:informs the reactor control room personnel that the rabbit has failed to return and is apparently still in the reactor core. Experimenter 2 and Hazards Control Technician 2 go to the reactor dome to inspect the equipment. During their checkout of the malfunction, the rabbit explodes. The explosion, simulated by a recording, is heard over the loudspeaker 
system in the control room. Simulated radiation levels from $500 \mathrm{R} / \mathrm{hr}$ at Experimenter 2 to $1000 \mathrm{R} / \mathrm{hr}$ at the airlock entrance to the dome cause the recalibrated dome radiation alarms to go off.

As a result of the explosion in the seactor dome, Hazards Control Technician 2 and Experimenter 2 are wounded and their wounds and clothing radioactively contaminated. Both attempt to escape by running down the stairs toward the emergency escape doors. Experimenter 2 panics, slips, and falls to the reactor balcony where he is conscious but immoliluzed with a broken back. Tho Hazards Control Technician proceeds, apparently unaware of the experimenter's accident, and exits through the come emergency escape joors. He runs to the reactor control room to report the accident, He simulates great pain and panic and forgets that he is possibly contaminated until reminded. Following the technician's report, the Reactor Supervisor gives emergency instructions to the Reactor Operator. At the instructions of the supervisor, the Reactor Operator places an emergency telephone call that is announced on the radio. What remains is for the support teams to respond to the exercise as they are notified and to act according to the disaster plans for a quick and successful conclusion to the problem.

First to respond to the call and to arrive in the street outside the building, about a minute after the official start of the exercise are the Fire Captain and the police. The Fire Captain makes an initial sizeup of "no smoke or flame visible" and the police secure the street.
In the first five minutes atter the emergency telephone call is placed, a fire truck arrives as do the Fmergency Control Coordinator, the Hazards Control Area Representative for the reactor, and a Health Physicist. According to the IPTR Disaster Plan and the exercise script, the Emergency Control Coordinator is in charge of the exercise. His first action upon arriving at the scere is to set up a Command Post, From it, he will centralize the control of all the activities, decide the general course of action, and direct the activities of the various emergency response groups when they are called out (Appendix B gives the Disaster Exercise Command Post Check1ist.) The Reactor Supervisor radios the Emergency Control Coordinator from the reactor control room and tells him details of the accident. The supervisor stays in the reactor control room and continues to inform and advise the Emergency Control Coordinator throughout the exercise.

About this time, two controlled access barricades (Hot Lines) are set up at the front door of the LPTR building. Two firemen change into protective clothing and Scott-air pak breathing devices to prevent raciation contamination. They enter the reactor building with a meter and note that the radiation level is $1000 \mathrm{R} / \mathrm{hr}$ (Fig. 6). They radio this information to the Emergency Control Coordinator at the Command Post. Because of the extremely high radiation level, the coordinator upgrades the accident to disaster status and orders that the LLL Disaster Organization be activated. Two of its support groups, the Emergency Evaluation Team and the Emergency 


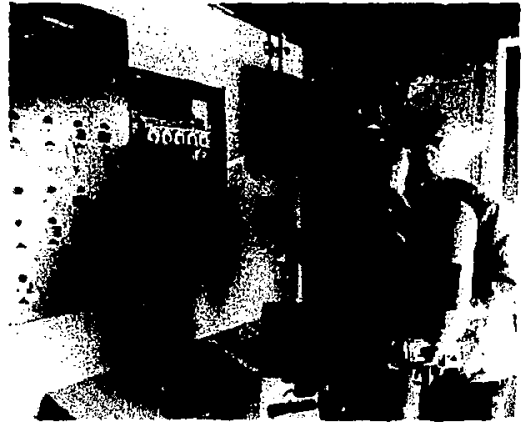

Fig, 6. Firemen enter the reactor building and check the radiation anel near the entrance.

Assistance Team, are also called out. Smnke bombs are activated throughout the exercise to learn the wind direction, action is taken to avoid being downwind of the reactor building, and air samples are taken to learn of any airborne radioactive contamination. These actions are repeated many times throughout the exercise.

The two firemen in the reactor building proceed to the control room, discover and give first aid to injured Hazards Control Technician 2, and then proceed to the reactor dome area where they discover Experimenter 2 in a $500 \mathrm{R} / \mathrm{hr}$ field (Fig. 7). They give him first aid and prepare him for removal.

About this time, the Deputy Disaster Control Director arrives, is briefed by the Emergency Control Coordinator, and discusaes the reactor conditions with the Hazards Control Reactor Aria Representative. The representat: ive helps the Fmergency Control Coordinator throughout the exercise by coordinating all technical zosistance necessary from emergency response personnel and by directing the activities of the Hazards Control technicians and the emergency reaponse teams. At approximately this point in the exercise, a requeat is made for a Hot Spot Decontamination trailer, the Environmental Evaluation Team is instructed to report to tie Hazards Control Area Representative, and one member each of the Criticality Safety Committee and the Industrial Safety Group arrives at the Command Post. Also, the player acting as newsman arrives at the West Gate of LLL. He aays that he monitored an ILI radio dispatch indicating that a disaster is occurring and demands a newa release. He threatens to release an alarmist news atory he has written if he is not given an official one. He continues to harass the gate guards throughout the exercise until the Public Information Office provides him with a release.

Twenty minutes into the disaster, members of the Environmental Evaluation Team and the Emergency Arsistance Team arrive. (Appendix $\mathrm{C}$ shows the Envirof mental Evaluation Team's cherk1ist.) The Emergency Assistance Team members put on their protective clothing (Fig. B). They then perform a radiological survey outaide the reactor building, activate a downwind sampler, and set up the Hot Spct Decontamination trailer.

At 24 minutes, two requested vehicles, a respirator truck and ambulance, arrive; the wind sampler showe the wind uas shifted and the emergency apparatus is moved upwind; and the firemen in the reactor zone attempt to exit with wounded Experimenter 2. However, they are trapped when an airlock door fails to open because another door has been left 
slightly ajar. The umpires step in to engure the continuance of the exercise and help the $d$ open the door. Thirty-five minutes after time zero, the firemen bring ti.e experimenter to the Hot Line (Fig. 9). He is decontaminated and then traneferred by ambulance to the Medical Department for further decontamination and treatment of his wounds.

Throughout the exercije, supervisory personnel confer at the Command Post (Fig. 10). At 42 minutes, the Deputy Disaster Control Director contacts the Disaster Control Director and briefs him. He asks the Director to make the necessary notifications, including the San Francisco AEC office and other outside agencies (see notifications, Appendix C). Also at this time, the firemen reenter the reactor building and proceed to the reactor control room to rescue Hezards Control Technician 2 (Fig. 11). Emergency Assistance Team members have entered the building by this time and they aid in the rescue. The second victim, Hazards Control Technician 2 is taken to the Hot Line, decontaminated, and then sent to the Medical Department (Fig. 12) via ambulance.

The Hazards Control technicians and the Emergency Assistance Team continue their activities to bring the reactor under control. They determine that the reactor rods are damaged and suggest a threepart solution. First, the reartor, which has been losing water as a result of the explosion, should be kept cool by running water. Second, borax should be added to the running water to decrease the radiation coming from the reactor. And third, repair of the damaged rods should begin. However, none of these actions are

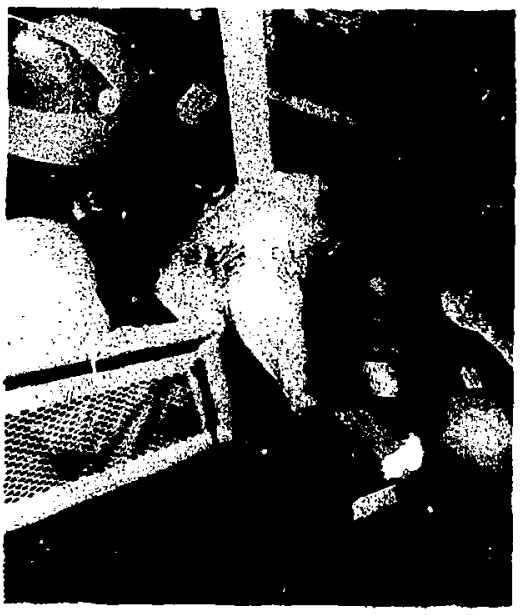

Fig. 7. Firemen discover Experimenter 2 in the reactor dome area.

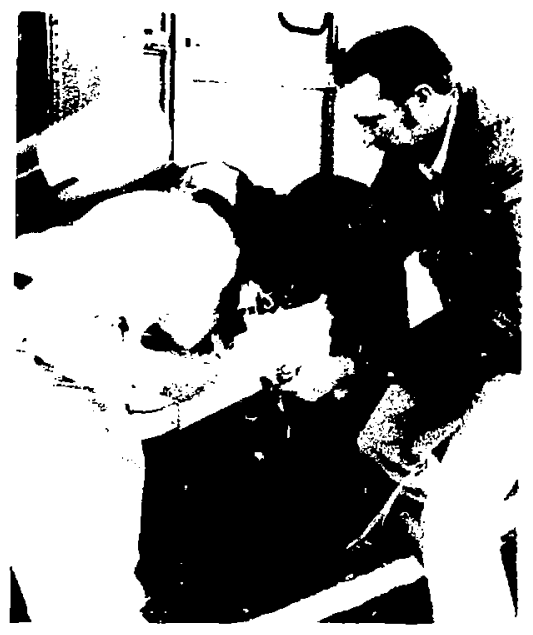

Fig. 8. An Emergency Assistance Team nember suits up. 


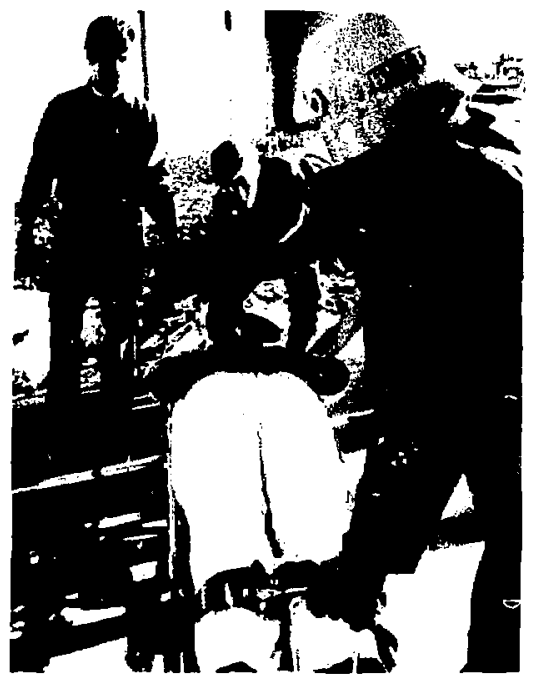

Fig. 9. Experimenter 2 brought to Hot Line.



Fig. 10. The Reactor Supervisor, Fire Captain, and Health Physicist confer at the Command Post.

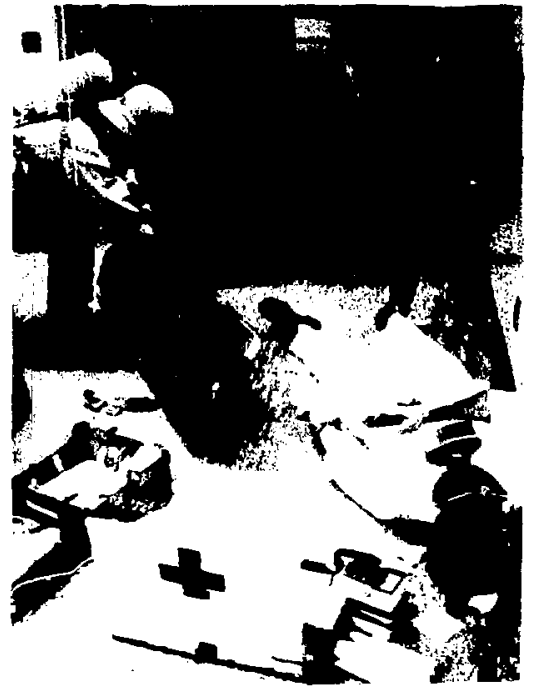

Fig. 11. Firemen prepare to remove Hazards Control Technician 2 from the reactor control room.

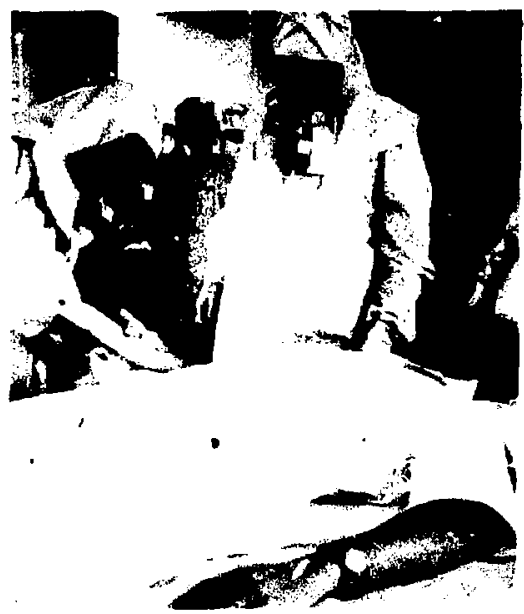

Fig. 12. Hazards Control Technician 2 receives treatment in special Medical Department decontamination facility. 
actually taken because all the conditions of the reactor problem are simulated.

At this point, the Reactor Supervisor indicates that the evaluation of the reactor damage problem has been completed and the reactor "brought under control," and, therefore, the exercise is concluded.

At completion, other desired actions have been accompliahed. They are:

- Both victims have been processed through the Medical Department.
- The Environmental Evaluation Team has completed its survey of off-site radiation release.

- The Emergency Assistance Team has removed the victims, processed them to Medical, secured the reactor area against the spread of radioactive contamination, and been released by the Deputy Disaster Control Director.

- The newrman at the West Gate has been provided with a news story.

\section{Critique}

Post-activity critiques and discussions of Exercise Super-Rabbit were just as important as the actual event because the exercise was intended primarily as a learning experience. Its whole purpose was to test and discover the strengths and weaknesses of the disaster control organization and to find ways in which the disaster response capabilities of LLL employees could be improved.

Two different types of critiques were held after Super-Rabbit, and everyone who participated in the exercise was involyed in at least one of these. First, each umpire met with his assigned group and critiqued their response. Then he attended the umpires' and coordinators' meeting and summarized his observations of, and recommendations for, his assigned group. A videotape film review was held at this second session. The Emergency Control Coordinator summarized the results of this critique session.

The general post-exercise consensus was that, overall, the exercise was very successful. People responded competently and the LPTR plan was effective. This was particularly commendable because it was the first time the LPTR plan had actually been tested, because it was such a large scale exercise, and bec: 2 many of the participating people were new at their jobs or had never before been involved in a disaster exercise.

A number of useful recommendations resulted from the critique process. They were utilized to improve the overall emergency response effectiveness of the entire disaster control organization. These included changes in the LLL and LPTR Disaster Plans, modiIication of emergency response operational procedures, improvement of response coordination activities, and retraining of emergency response support personnel. The recommendations can be divided into three areas that need improvement: communications, organization, and radiation safety. Specific sugges.ton follow.

\section{COMMUNICATIONS}

Various suggestions were made concerning improving communications. For 
example, the Medical Department and the Fire Department need to communicate better in the handling and decontaminating of accident victims. In future exercises, the Fire Department ghould label the victims as to the nature of injurie日; type, degree, and location of contamination; and first aid given; and, they should radio sizeups of the victimg' conditions to the Medical Department before transporting them there. All these actions will save time in treating victims and are a normal part of LLL disaster control.

Areas in which communicatic ns between the Environmental Analys.. Team and the two groups that assist it, the Analytical Laboratory and the Meterology Group, could be improved were \& 1 ggested. The Analytical Laboratory should he notified that the Environmental Analysis Team $\mathrm{h}$ as been activated, it should be given complete instructions with each sample that is being analyzed, and it should be given a priority system for analyzing samples. The Meterology Group should have a radio to improve their communications with the Command Post and the words "Emergency Services" on their badges to expedite data gathering.

In future exercises, the evacuees should be monitored and briefed on the accident that has occurred, and assembled in a specific area or released. The Health Physicist should ensure that people have been monitored and decontaminated, and the Hazards Control Reactor Area Representative or the Emergency Control Coordinator should see that the Senior Building Supcrvisor attends to the evacuees. Communication can also be improved if the Senior Fire Officer or the firemen who first enter the building contact the building reactor personnel to get their assesement of the accident.

A few suggestions were made concerning the overall improvement of communications. An Emergency Control Center should be established, posaibly at the Folice Department Building. Technical advisors arriving at the accident scene should be directed to a designated assembly point, briefed aboui the situation by the Disaster Director, and given specific jobs to accompliab. A supplemental radio system should be used to alleviate the considerable radio trafic during the exercise. Suggestions for the supplemental system include the LLL taxi cab freqtency, citizen uand receivers, and sound-powered phones. The emergency dispatchers should have an automatic log keeping system so that the rapid equence of events can be recalled for post-accident analysis.

\section{ORGANIZATION}

The post-exercise critiques resulted in a number of suggestions for the iraprovement of organization. For example, the Emergency Assistance Team assigaments should be consistent with the overall plan. The team should first conduct an additional radiation survey of the accident scene, and then aid with the rescue of victims. After they have completed these activities, they can proceed with their other tasks. The Medical Department should have enough extra people avallable to be litter bearers, radiation monitors, and to drive ambulances. In any accident situation, those near a trapped victim should provide him with first aid. In Super-Rabbit, the reactor 
operators did not aid injured Hazards

Control Technician 2.

\section{RADIATION SAFETY}

Improvements were suggested in the area of radiation safety. The need for greater caution with high radiation situations was one of the main lessons learnec' from Exercise Super-Rabbit. Radiation levels should be constantly monitored by the personnel at the accident scene. The Hazards Control Reactor Area Representative and the Hazards Control Health Physicist should both take an active role in insisting on constant monitoring and ensuring that the radiation levelg are known. All members of the disaster organization should be aware that exposure to emergency doses exceeding $25 \mathrm{R}$ must be voluntary.

The use of radiation meters should be improved. Suggestions included: nigh range radiation meters should be used when estering potentially bigh radiation fields; monitoring personnel should use at least two meters; meters used in radiation surveys should not be placed on potentially contaminated surfaces; and radiation monitoring should be performed continuously to establish any change that might occur in the radiation field.

Various suggestions were made for greater care in the area of airborne radiation contamination. They included: the need for breathing apparatus should be constantly reviewed; all people in the radiation area thuuld evaluate their need for respiratory protection; the possibility of contamination during the changing of breathing apparatus bottles should be studied; potentially contaminated clothing should not be removed without respiratory protection; and victims gent to the Medical Department should be stripped and decontaminated.

Improvemenits were suggested in the control of downwind contamination. Wind direction should be carefully noted and the Command Post should continually announce the correct approach route over the radio. Building air samplers should be set up as early as possible. Other suggestions were: rescue personnel left downwind should be provided with appropriate clothing and an intermediate hot zone should be estab] ' 'hed at the accident scene.

\section{Commenta}

The careful planning that went into Exercise Super-Rabbit contributed to its success. Attention was given to realism, constraints and limitations, sarety precautions, and post-exercise analysis. Any large scale exercise should be planned with consideration to the above areas if a useful learning experience is to be the result.
Realism can be produced by thoroughly researching the activity to be simulated and rehearsing the exercise script. An individual who experiences realism will always react more reliably in an actual situation.

Constraints and limitations are needed to bring the specific areas to be exercised into focus. Such controls are alsn needed 
to start, stop, and guide the flow of action in an exercise. An exercise which starts prematurely, stope too soon, or rung too long loses its usefulness.

Safety precautions are also imperative in fast-paced and emotionallycliarged exerciaea, such as SupyRabbit, where there may be danger of personal injuries and of compromlsing the safety of the facilities being used. Umpires are necessary to supervise the activities; and an exercise safety officer is required who has overall responsibility for conducting a safe exercise and the authority to stop the exercise at any time.

To judge the effectiveness of the exercise, feedback is required. VIdeotapes or other media can be utilized to document and review the results. The umpires should participate in critique cessions. These are needed to elicit and to formalize the remedial actions neceas ary to improve the response. 


\section{References}

1. Disaster Control Plan, compiled by Hazards Control De Jartment, Lawrence 1.ivermore Laboratory. Rept. M-014 (1973).

2. "livermore Pool Type Reactor Disaster Control Plan," in Qperational Safety Procedures, compiled by the Hazards Control Department, Lawrence Livermore Laboratory, Procedure 281, Appendix A (1973).

3. Health and Safety Manual, compiled by the Hazards Control Department, Lawrence Livermore Labc:átory, Rept. M-010 (1973).

4. Hazards Control Manual, compiled by the Hazards Control Department, Lawrence Livermore L.aboratory, Rept. M-017 (1973). 


\section{Appendix A \\ Disaster Exercise General Checklist}

PUBLIC RFI.ATIONS

\begin{tabular}{|c|c|c|c|}
\hline Press release prepared & $\overline{y e s}$ & no & By uhom \\
\hline Building occupants briefed & & & By whom \\
\hline Emergency workers briefed & & & By whom \\
\hline Employee notice prepared & & & By whom \\
\hline & yes & no & \\
\hline Press conference called & & $\overline{n 0}$ & By whom \\
\hline
\end{tabular}

EMERGENCY SUPPLIES

\begin{tabular}{|c|c|c|c|c|c|c|c|c|}
\hline Gasoline & $\overline{\text { yes }}$ & no & Lighting & yes & no & Oxygen & $\overline{y e s}$ & no \\
\hline Charcoal filter & $\overline{\text { yes }}$ & $\overline{\mathrm{no}}$ & Hard hats & $\overline{y e s}$ & $\overline{\text { no }}$ & TV equipment & yes & no \\
\hline Transportation & $\overline{y e s}$ & $\overline{\text { no }}$ & Protective & clothi & & no & & \\
\hline
\end{tabular}

NOTIFICATION

\begin{tabular}{|c|c|c|c|c|c|}
\hline Disaster Director & $\overline{y e s} \overline{n o}$ & $\begin{array}{l}\text { Hazards Control } \\
\text { disciplines }\end{array}$ & yes ño & $\begin{array}{l}\text { Public Information } \\
\text { Office }\end{array}$ & yes $\overline{\text { no }}$ \\
\hline $\begin{array}{l}\text { Deputy Disaster } \\
\text { Director }\end{array}$ & $\overline{\text { yes }} \overline{\text { no }}$ & $\begin{array}{l}\text { AEC San } \\
\text { Francisco }\end{array}$ & $\overline{\text { yes nu }}$ & AEC Washington & ges no \\
\hline Radiation Group & $\overline{\text { yes }} \overline{\text { no }}$ & Site 300 & yes $\overline{\text { no }}$ & $\begin{array}{l}\text { Medical } \\
\text { Department }\end{array}$ & yes no \\
\hline Next of kin & $\overline{\text { yes }} \overline{\text { no }}$ & Coroner & $\overline{\text { yes }} \overline{\text { no }}$ & City of livermore & yes no \\
\hline $\begin{array}{l}\text { Hazards Control } \\
\text { Area Repre- } \\
\text { sentative }\end{array}$ & $\overline{\mathrm{yes}} \overline{\mathrm{no}}$ & $\begin{array}{l}\text { Building } \\
\text { Coordinator }\end{array}$ & $\overline{\text { yes }} \overline{\text { no }}$ & FBI & yes no \\
\hline Newsline & yes $\overrightarrow{n o}$ & $\begin{array}{l}\text { Valley Memorial } \\
\text { Hospital }\end{array}$ & $\overline{\text { yes }} \overline{\text { no }}$ & County Sheriff & $\overline{\text { yes no }}$ \\
\hline
\end{tabular}


INCIJENT CI.A.SSIHICATIOX

Class A $\overline{y e s} \overline{\text { no }}$ Class $13 \frac{}{\text { yes }} \bar{\omega}$ Class C $\overline{y e s} \overline{\text { no }}$

Incident report needed एеs तुo By whom

Firemen spot at hydrant $\overline{\text { yes }} \overline{\text { no }}$

Enter by main entrance

Firemen check panel $\overline{\text { yes }} \overline{\text { no }}$

Recuver nuclear accident dusimeter yes $\overline{\text { no }}$

-heck wind in control room panel $\overline{\text { yes }} \overline{\text { no }}$

\section{EMERGENCI ACTIONS}

Material identified

Stay times set

Two meters used

Road blocks

\section{Disconnect}

Power

Water

Gas

Air

Ventilation

Steam

Klaxons shut of

$$
\begin{aligned}
& \overline{\text { yes }} \overline{\text { no }} \\
& \overline{\text { yes }} \overline{\text { no }}
\end{aligned}
$$$$
\text { Radiation levels }
$$$$
\text { determined }
$$$$
\text { yes } \overline{\text { no }}
$$

Stay times observed

$\overline{\text { yes }} \overline{\text { no }}$

$$
\overline{\text { yes }} \overline{\text { no }}
$$

$$
\overline{y e s} \text { no Where }
$$

$$
\overline{y e s} \overline{\text { no }}
$$

Area

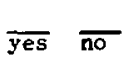

Area

$$
\text { yes no }
$$

Area

yes $\overline{\text { no }}$

Area

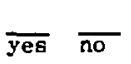

Area

$$
\overline{\text { yes }} \overline{\text { no }}
$$

Area

$$
\overline{y e s} \overline{\text { no }}
$$

Smoke bomb

$\overline{y e s} \overline{\text { no }}$ 


$\begin{array}{lll}\begin{array}{l}\text { Dispatcher operates } \\ \text { evacuation paging } \\ \text { system }\end{array} & \overline{\text { yes }} & \overline{\text { no }} \\ \begin{array}{l}\text { Disaster trailer } \\ \text { needed }\end{array} & \overline{\text { yes }} & \overline{\text { no }} \\ \begin{array}{l}\text { Emergency morgue } \\ \text { needed }\end{array} & \overline{\text { yes }} & \overline{\text { no }}\end{array}$

Dispocher gives
wind direction
on radio

Where

Where 


\section{Appendix B \\ Disaster Exercise Command Post Checklist}

COMMAND POSN OPERATIONS

Command Poet

\begin{tabular}{|c|c|c|c|c|c|c|c|}
\hline \multirow{2}{*}{ In safe location } & \multirow[b]{2}{*}{ yes } & \multirow[b]{2}{*}{ n̄o } & \multirow[b]{2}{*}{ Senior Police } & \multicolumn{2}{|c|}{ Check-In } & \multicolumn{2}{|c|}{$\begin{array}{c}\text { Stayed at } \\
\text { Command Post }\end{array}$} \\
\hline & & & & $\overline{\text { yes }}$ & $\overline{\text { no }}$ & $\overline{\mathrm{yes}}$ & $\overline{\text { no }}$ \\
\hline Lpwind & yes & no & Area Representative & $\overline{\text { yes }}$ & & $\overline{\text { yes }}$ & no \\
\hline Up hill & $\overline{\text { yes }}$ & no & Health Physicists & $\overline{\text { yes }}$ & no & $\overline{y e s}$ & $\overline{\text { no }}$ \\
\hline Contaminated & yes & no & $\begin{array}{l}\text { Emergency Assistance } \\
\text { Team }\end{array}$ & $\overline{\text { yes }}$ & no & $\overline{\text { yes }}$ & no \\
\hline Away from traffic & $\overline{\mathrm{yes}}$ & no & $\begin{array}{l}\text { Environmental } \\
\text { Evaluation Team } \\
\text { Senior Fire Officer }\end{array}$ & $\overline{y e s}$ & no & $\overline{y e s}$ & no \\
\hline $\begin{array}{l}\text { Location } \\
\text { announced on } \\
\text { air }\end{array}$ & $\overline{\text { yes }}$ & $\overline{\text { no }}$ & $\begin{array}{l}\text { Disaster Control } \\
\text { Director }\end{array}$ & $\overline{\text { yes }}$ & $\overline{\text { no }}$ & $\overline{y e s}$ & $\overline{\text { no }}$ \\
\hline Sizeup given & $\overline{\mathrm{yes}}$ & $\overline{\text { no }}$ & $\begin{array}{l}\text { Deputy Disaster } \\
\text { Control Director }\end{array}$ & $\overline{\text { yes }}$ & no & $\overline{\text { yes }}$ & $\overline{n o}$ \\
\hline $\begin{array}{l}\text { Command Post } \\
\text { flag used }\end{array}$ & yes & no & $\begin{array}{l}\text { Building } \\
\text { Representatives }\end{array}$ & yes & $\overline{n o}$ & $\overline{\text { yes }}$ & no \\
\hline
\end{tabular}

RADIATION CONTRCL ZONES

\begin{tabular}{|c|c|c|c|c|c|c|c|c|}
\hline \multirow{3}{*}{$\frac{\text { Zones }}{\text { Hot zone }}$} & \multicolumn{2}{|c|}{ Defined } & \multicolumn{2}{|c|}{ Adequate } & \multicolumn{2}{|c|}{ Respected } & \multicolumn{2}{|c|}{ People Logged In } \\
\hline & & & & & & & & \\
\hline & $\overline{y e s}$ & no & $\overline{y e s}$ & $\overline{\text { no }}$ & $\overline{\text { yes }}$ & $\overline{\text { no }}$ & $\overline{\text { yes }}$ & $\overline{\text { no }}$ \\
\hline Interme jiate zone & & & & & & & & \\
\hline & yes & no & $\overline{y e s}$ & no & yes & no & yes & no \\
\hline
\end{tabular}

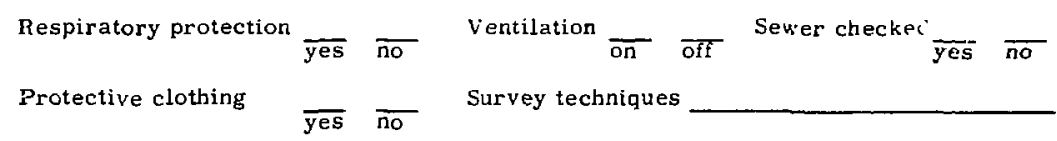

$\underline{\text { Remarks }}$ 


\section{Appendix C \\ Environmental Evaluation Team Checklist}

ENVIRONMENTAL EVALIATION TEAM

Team captain notified

$\overline{\text { yes }} \overline{\text { no }}$

By whom

W.'en

Team callout started by

When

Completed

Commerits

Environmental Evaluation Team (on-site) activated: $\overline{\text { yes }} \overline{\text { no }}$

Assignment (s)

Environmental on-site team vehicles obtained from

Adequate two-way radios available from Fire Department

$\overline{\text { yes }} \overline{\text { no }}$

ME'TEROLOGICAL GROUP

Meterological advisor available $\overline{\text { yes }} \overline{\text { no }}$

Who Hazards Control Meterology supplying data

to Meterological Group $\overline{\text { yes }} \overline{\text { no }}$

Comments

Meterological Group analyzing meterology data and supplying wind direction, speed, and dilution data. Trajectory map from Meterology Group

$$
\overline{y e s} \overline{\text { no }}
$$

Comments 
Back-up teams (off-site and on-site) assembled and available at Fire Station $\overline{\text { yes }} \overline{\text { no }}$ When Comments

\section{Perim ter teams deplcyed (off-site)}

Route 1

$$
\text { yes: } \overline{\text { no }}
$$

Route 2

$$
\text { yeș } \overline{\text { no }}
$$

Route 3

$$
\overline{\text { yẹs }} \overline{\text { no }}
$$

Perimeter vehicles obtained from

\begin{tabular}{|c|c|c|}
\hline$\vdots$ & yes & no \\
\hline Hazards Control Analytical Laboratory & $\overline{\text { yes }}$ & $\overline{n o}$ \\
\hline Bio-Medical Tritium Group & yes & no \\
\hline Bio-Medicąl Van & $\overline{\text { yes }}$ & no \\
\hline Radiochemistry Group & $\overline{\text { yes }}$ & $\overline{\mathrm{no}}$ \\
\hline Home a ri; samplers activated & $\overline{\text { yes }}$ & no \\
\hline
\end{tabular}

\section{Support activated}

\section{Hazards Control Counting Room}

General Comments

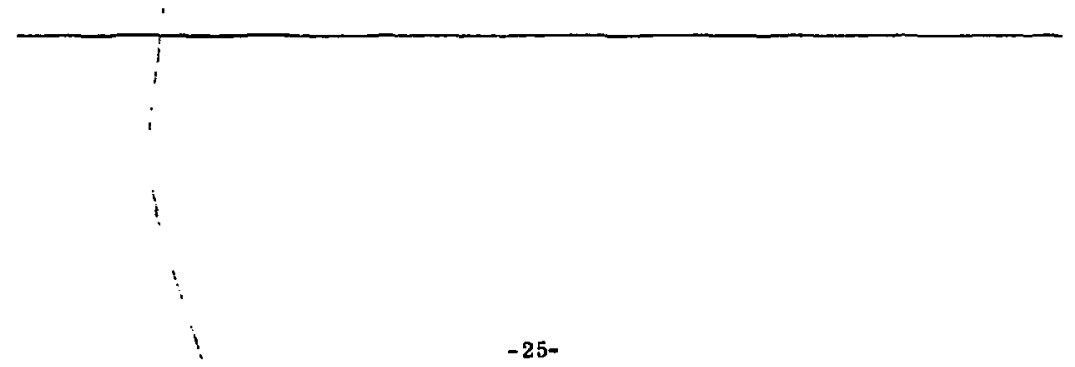

